\title{
Suggestions expressed by the officials of project and non-project areas in tank management
}

\author{
P. PRASHANTH, M. JAGAN MOHAN REDDY, KOTA TIRUPATAIAH, I. SREENIVASA RAO AND \\ A. SRINIVAS
}

Article Chronicle:

Received:

15.10.2015;

Revised :

05.11.2015;

Accepted :

18.11.2015

Key Words :

Tank management, Officials, Project

Areas, Non-

project areas
ABSTRACT :The paper reveals that earlier various tank management policies are never implemented, but integrated through the negotiation with other diverse policies and socio-economical, technological settings in (re) shaping tank management. The analysis demonstrates that water is managed by multifaceted governance arrangements i.e. WUAs, government, participatory groundwater users, officials, commodity interest groups, gender groups and tribal groups. Ex-post facto research design was adopted for this study. The state of Telangana and Andhra Pradesh, three districts (Mahaboobnagar from Telangana; Vizianagaram from Coastal Andhra, Chittoor from Rayalaseema) were selected purposively. For these study, officials were selected both from project and non-project tank areas in each district. From the tanks operated under project area in each selected district 10 members of officials were selected randomly who are discharging the mandate of APCBTMP. Whereas, from the tanks operated under non-project area in each selected district 10 members of officials are selected randomly representing department of agriculture and I and CAD department. Thus, comprising a total of 60 officials were selected for the study. Suggestions expressed by the officials of project and nonproject area in tank management were grouped into four categories namely job related, organization related, technical related and finance related categories. The suggestions under each category were ranked based on frequency and percentage.

HOW TO CITE THIS ARTICLE : Prashanth, P., Reddy, M. Jagan Mohan, Tirupataiah, Kota, Rao, I. Sreenivasa and Srinivas, A. (2015). Suggestions expressed by the officials of project and non-project areas in tank management. Asian J. Environ. Sci.,10(2): 161-165.

Author for correspondence :

\section{P. PRASHANTH}

College of Agriculture, (PJTSAU) Jagtial, KARIMNAGAR (TELANGANA) INDIA Email: Prashanth897@ gmail.com

See end of the article for Coopted authors' 